\title{
Response surface methodology as a statistical tool for optimization of removal of chromium (VI) from aqueous solution by Teff (Eragrostis teff) husk activated carbon
}

\author{
Tsegaye Adane ${ }^{1}\left[\right.$ D $\cdot$ Daniel Haile ${ }^{1} \cdot$ Awrajaw Dessie $^{1} \cdot$ Yohannes Abebe $^{2} \cdot$ Henok Dagne $^{1}$
}

Received: 4 July 2019 / Accepted: 10 December 2019 / Published online: 21 December 2019

(C) The Author(s) 2019

\begin{abstract}
Recently, rapid industrialization leads to excessive release of heavy metals such as $\mathrm{Cr}(\mathrm{VI})$ in the environment. Exposure to chromium (VI) can cause kidney and liver damage, depressed immune systems, and a variety of cancers. Therefore, treatment of $\mathrm{Cr}(\mathrm{VI})$ containing wastewater is mandatory. This study aims to optimize the removal of $\mathrm{Cr}(\mathrm{VI})$ from aqueous solution using locally available Teff husk activated carbon adsorbent. The laboratory-based study was conducted on the optimization of $\mathrm{Cr}(\mathrm{VI})$ removal efficiency of Teff husk activated carbon from aqueous solution. A central composite design was used to examine the effect of the interaction of process parameters and to optimize the process using Design Expert version 7.0 software. The optimized removal efficiency of Teff husk activated carbon $(95.597 \%)$ was achieved at $1.92 \mathrm{pH}, 87.83 \mathrm{mg} / \mathrm{L}$ initial concentration, $20.22 \mathrm{~g} / \mathrm{L}$ adsorbent dose, and $2.07 \mathrm{H}$ contact time. The adsorption of $\mathrm{Cr}(\mathrm{VI})$ on Teff husk activated carbon was found to be best fitted with pseudo-second-order kinetics and Langmuir isotherm model of the adsorption. Teff husk activated carbon can be used as an efficient adsorbent for removal of chromium (VI) from contaminated water. Column adsorption needs to be studied in the future.
\end{abstract}

Keywords Batch adsorption $\cdot$ Chromium (VI) $\cdot$ Teff husk activated carbon $\cdot$ Central composite design

\section{Introduction}

The generation rate of wastewater is increasing dramatically worldwide due to the increased consumption of water. Globally, over $80 \%$ of the wastewater is discharged to the environment without prior treatment (UN-WWAP 2017). The problem is severe in developing countries because they discharge more than $90 \%$ of the wastewater into the environment without proper treatment. In the $21^{\text {st }}$ century, the rapid

Electronic supplementary material The online version of this article (https://doi.org/10.1007/s13201-019-1120-8) contains supplementary material, which is available to authorized users.

Tsegaye Adane

tseg729@gmail.com

1 Department of Environmental and Occupational Health and Safety, Institute of Public Health, College of Medicine and Health Sciences, University of Gondar, Gondar, Ethiopia

2 Department of Chemistry, College of Natural and Computational Sciences, University of Gondar, Gondar, Ethiopia industrialization leads to excessive release of heavy metals into the environment, which has a significant adverse effect on human health and the environment (Sato et al. 2013). Recently, chromium pollution is a heavy metal pollution that has been a major focus of researchers (Renuga et al. 2010). Chromium may be found as $\mathrm{Cr}(\mathrm{III})$ and $\mathrm{Cr}(\mathrm{VI})$ in industrial wastewater (Mullick et al. 2017). Its hexavalent form has gotten a great concern due to its hazardous property and carcinogenic to exposed peoples (Renuga et al. 2010; Zhang et al. 2012).

$\mathrm{Cr}(\mathrm{VI})$ adversely affects the kidney and liver and causes dermatitis, diarrhea, mouth ulcers, nosebleeds, low white blood cell counts-hence depressed immune defense systems, miscarriages, and a variety of cancers (Solomon 2008; Singh and Singh 2012). According to the Blacksmith Institute's world worst pollution problems, chromium pollution adversely affects about 16 million people in 2015 globally (Black-Smith-Institute 2015). In aquatic ecosystems, chromium is known to bioaccumulate in algae, aquatic plants, invertebrates, and fish. Toxicological studies proved that hexavalent chromium, even at relatively low concentrations, can cause reduced growth and photosynthesis in algae and 
aquatic plants; and lethal toxicity, behavior changes; and decreased growth, reproduction and survival in invertebrates; and changes in physical and bio-chemical conditions, increased hatching time, DNA damage, and reduced survival in fish (MiningWatch 2012). For instance, 62 ppb of $\mathrm{Cr}(\mathrm{VI})$ inhibits growth in algae and $16 \mathrm{ppb}$ inhibits growth in fish (Solomon 2008).

In Ethiopia, currently there are more than 30 tannery industries in operation. Most of the Ethiopian leather industry uses chrome tanning and discharges their wastewater to nearby water bodies without adequate treatment. As a result, it adversely affects the aquatic ecosystem and the community around the river that uses the water bodies for drinking, personal hygiene, irrigation, etc. The effluent concentration of $\mathrm{Cr}(\mathrm{VI})$ in most of the industries in Ethiopia is in the range of $28-45 \mathrm{mg} / \mathrm{l}$ (Birhanie et al. 2017), which is much greater than the WHO and Ethiopian Environmental Protection Authority (EEPA) standard value of $0.1 \mathrm{mg} / \mathrm{l}$ (Kebede and Gashaw 2016). In view of the pollution hazard caused by $\mathrm{Cr}(\mathrm{VI})$, treatment of wastewater to remove excess chromium is imperative.

Several technologies have been applied to remove $\mathrm{Cr}(\mathrm{VI})$ from aqueous solutions including precipitation, reverse osmosis, ion exchange, filtration, sand filtration, chemical reduction/oxidation, electrochemical precipitation, membrane filtration, solvent extraction, and electrochemical deposition. However, all of these techniques suffer from various limitations including incomplete metal removal, high reagent consumption and energy utilization, low selectivity, and generation of secondary wastes that are difficult to dispose off (Tesfaye 2016; Azimi et al. 2017; Aravind et al. 2016). Thus, adsorption is the best suited method that can be used in low income countries like Ethiopia due to its inexpensiveness and efficient removal of heavy metals. Due to its high-porosity, activated carbon (AC) is one of the most commonly used alternatives for the removal of $\mathrm{Cr}(\mathrm{VI})$ from drinking and wastewater (Zhang et al. 2012). Therefore, it is important to find a way to remove hexavalent chromium using inexpensive adsorbents.

In the present study, an activated carbon that is produced from Teff husk, an agricultural solid waste obtainable from Teff (Eragrostis Teff), was utilized for the removal of $\mathrm{Cr}(\mathrm{VI})$ from aqueous samples. Teff (E. Teff), a cereal crop that belongs to the grass family Poaceae, is endemic to Ethiopia. It is the most common and native cereal crop mainly produced in Ethiopia with the largest share of cultivation, over 2.8 million hectares (25-30\%) (Kibatu et al. 2017). It is primarily cultivated for its grain for human consumption and its straw and husk for livestock forage. It is also cultivated in most of the country especially in the highlands and able to grow under a wide range of ecological conditions such as on waterlogged area to drought environments. Teff husk is abundant, locally available, and low-cost agro-waste in Ethiopia (Vandercasteelen et al. 2013; Stallknecht et al. 1993; Gebretsadik et al. 2009). Therefore, Teff husk can be used as a potential precursor for the production of low cost activated carbon. No research has been done on the optimized application of THAC for removal of $\mathrm{Cr}(\mathrm{VI})$ from an aqueous solution. The purpose of this research is to optimize the efficiency of low-cost, locally available Teff ( $E$. Teff) husk activated carbon for removal of chromium (VI) from aqueous solution.

\section{Methods and materials}

\section{Experimental design}

A laboratory-based experimental study was conducted at the University of Gondar from March to June 2018 Gondar, Ethiopia.

\section{Chemical and reagents}

All chemical and reagents in this study were analytical grade (>99\% pure). Working $\mathrm{Cr}(\mathrm{VI})$ solutions were prepared from the stock solution $(1000 \mathrm{mg} / \mathrm{L})$ by successive dilutions using distilled water. The sample solution $\mathrm{pH}$ was adjusted by adding drops of either $\mathrm{NaOH}$ or $\mathrm{HCl}(1 \mathrm{M}$ each) solution whenever required.

\section{Preparation of the Teff husk activated carbon}

The Teff husk was collected from the farmers around Gondar using pre-cleaned polyethylene bags. The Teff husk sample was washed with distilled water and sun dried; followed by oven dried at $105{ }^{\circ} \mathrm{C}$ for $24 \mathrm{~h}$ to remove the excess moisture. The dried sample was mixed with $1: 3 \mathrm{w} / \mathrm{w} \%$ of conc. $\mathrm{H}_{2} \mathrm{SO}_{4}$ and kept at room temperature for $24 \mathrm{~h}$. Then, the solid residue was washed with distilled water and neutralized by soaking in $2 \% \mathrm{NaHCO}_{3}$ solution for a day. The product was also air-dried at room temperature and kept in hot air oven at $120^{\circ} \mathrm{C}$ for $10 \mathrm{~h}$ and then transferred to a muffle furnace kept at $550{ }^{\circ} \mathrm{C}$ for an hour (Yimer et al. 2014). Finally, the dried activated carbon was crashed and powdered into a sieve size of 1-2 $\mathrm{mm}$ and preserved in desiccators for further use (Tesfaye 2016).

\section{Characterization study of Teff husk activated carbon}

The Teff husk activated carbon was characterized in terms of its physical and chemical characteristics (Table 1). American Society for Testing and Materials (ASTM international) standard methods for characterization of activated carbon have been used as described in Table 1. The presence of various functional groups present on the surface of the 
Table 1 Standard methods applied to measure characteristics of THAC

\begin{tabular}{lll}
\hline $\begin{array}{l}\text { Characteristics of } \\
\text { THAC }\end{array}$ & Standard methods used & References \\
\hline $\begin{array}{l}\text { Carbon yield } \\
\text { Moisture content }\end{array}$ & $\begin{array}{c}\text { ASTM D2867-99 } \\
\text { method }\end{array}$ & $\begin{array}{l}\text { Emirie (2015) } \\
\text { ASTM (1999a) }\end{array}$ \\
$\begin{array}{l}\text { Volatile matter } \\
\text { method }\end{array}$ & ASTM (2003) \\
Ash content & $\begin{array}{c}\text { ASTM D2866-94 } \\
\text { method }\end{array}$ & ASTM (2004b) \\
$\begin{array}{l}\text { Fixed carbon } \\
\text { Bulk density and } \\
\text { porosity }\end{array}$ & $\begin{array}{c}\text { ASTM D2854-96 } \\
\text { method }\end{array}$ & ASTM (2004a) \\
$\begin{array}{l}\text { Specific surface area } \\
\mathrm{P}^{\mathrm{H}}\end{array}$ & $\begin{array}{c}\text { Sears method } \\
\text { ASTM D3838-80 }\end{array}$ & Yimer et al. (2014) \\
Point of zero charge & Solid addition method (1999b) & Emirie (2015) \\
\hline
\end{tabular}

adsorbent and their role in adsorption were also analyzed using FT-IR (Fourier transform infrared) spectrum within the range of $400-4000 \mathrm{~cm}^{-1}$ using FT-IR-65 Spectrometer.

\section{Batch adsorption experiments}

\section{Effect of individual process parameters}

Batch adsorption experiments were conducted to investigate the effect of $\mathrm{pH}$, initial concentration of $\mathrm{Cr}(\mathrm{VI})$, adsorbent dose, and contact time on $\mathrm{Cr}(\mathrm{VI})$ removal efficiency of THAC (Emirie 2015; Dula et al. 2014; Kakavandi et al. 2014; Ali et al. 2016; Ali and Alrafai 2016). The range of each of the four process parameters was determined based on previous studies as stated in Table 2 and taking the others variables constant.

Flasks containing $100 \mathrm{ml}$ of samples were agitated by using thermostatic shaker with $25{ }^{\circ} \mathrm{C}$ at $200 \mathrm{rpm}$ for all experiments. Then, the samples were filtered by using Whatman No.1 filter papers, and supernatant was analyzed for $\mathrm{Cr}(\mathrm{VI})$ ion concentration by flame atomic absorption spectrometer. The blank adsorption experiments were also carried out. Then, the removal efficiency of THAC was determined (Tesfaye 2016).

Removal Efficency $(\%)=\frac{C_{\mathrm{o}}-C_{\mathrm{t}}}{C_{\mathrm{o}}} \times 100$

Where $C_{\mathrm{o}}$ and $C_{\mathrm{t}}$ are the $\mathrm{Cr}(\mathrm{VI})$ concentrations in $\mathrm{mg} / \mathrm{L}$ initially and at a given time $t$, respectively.

\section{Optimization of process parameters}

The optimum adsorption conditions and the interaction of the four variables considered in this study were determined by response surface methodology (RSM) through facecentered central composite design (CCD) (Gnanasundaram et al. 2017). RSM is the best design to find the ideal process settings and achieve the optimal performance of a surface processes (Magoling and Macalalad 2017; Gnanasundaram et al. 2017). For each factors -1 and +1 levels were estimated from the batch experiment. Then 30 random runs generated by CCD and computed by the formula: $N=2^{\mathrm{f}}+2 f+f_{\mathrm{c}}$, where $\mathrm{f}$ is the number of factors and $f_{c}$ is the center runs, were tested. The adsorption process was conducted for each solution with three levels $(-1,0,+1)$ of $\mathrm{pH}$, initial concentration of $\mathrm{Cr}(\mathrm{VI})$ ions, dose of activated carbon, and contact time as described in Table 4. Then, the $\mathrm{Cr}(\mathrm{VI})$ removal efficiency of THAC and its optimum condition have been determined. Design expert software version 7.0.0 was used for the modeling and optimization experiment.

\section{Isotherm and kinetics studies}

Adsorption isotherm was also studied with different initial concentration of $\mathrm{Cr}(\mathrm{VI})(100,150,200,250 \mathrm{mg} / \mathrm{L})$ and optimum $\mathrm{pH}, \mathrm{AC}$ dose, and contact time. Then, equilibrium concentration $\left(C_{\mathrm{e}}\right)$, amount of adsorbed adsorbate at an equilibrium $\left(q_{\mathrm{e}}\right)$, and specific adsorption $\left(C_{\mathrm{e}} / q_{\mathrm{e}}\right)$ were calculated to determine the isotherm of the adsorption. Then, the isotherm was examined whether it is fitted to Langmuir isotherm model by plotting (plot $C_{\mathrm{e}} / q_{\mathrm{e}}$ vs $C_{\mathrm{e}}$ ) (eq. 3) or Freundlich isotherm model (plot $\log q_{\mathrm{e}}$ vs $1 / \log C_{\mathrm{e}}$ ) (eq. 4) using $R$-squared value (Tesfaye 2016).
Table 2 Ranges of process parameters at which adsorption test was conducted

\begin{tabular}{lll}
\hline Parameter to be examined & Range & References \\
\hline $\mathrm{pH}$ & $1,2,3,4,5,6$ & $\begin{array}{c}\text { Rai et al.(2016), Kebede and Gashaw } \\
(2016), \text { Emirie (2015), and Berihun } \\
(2017)\end{array}$ \\
& & $\begin{array}{c}\text { TESHOME (2015) and Rai et al. } \\
(2016)\end{array}$ \\
Initial Cr(VI) conc. (mg/L) & $50,100,150,200,250$ & Dula et al. (2014) \\
Adsorbent dose (gm) & $0.5,1,1.5,2,2.5$ & Berihun (2017) and Dula et al. (2014) \\
Contact time (h) & $0.5,1,1.5,2,2.5$ &
\end{tabular}


Adsorption kinetics was examined with batch adsorption by making conc. of $\mathrm{Cr}(\mathrm{VI}), \mathrm{pH}$ and, dose of $\mathrm{AC}$ at optimum condition with different the contact time $(0.5,1.0,1.5,2.0$ h). Then, the amount of adsorbed adsorbate at an equilibrium $\left(q_{\mathrm{e}}\right)$ and amount of adsorbed adsorbate at any instant of time $t\left(q_{t}\right)$ were calculated to determine the kinetics of the adsorption. Then, the adsorption kinetics was also tested whether it is fitted to pseudo-first order kinetics (plot log $\left(q_{\mathrm{e}}-q_{\mathrm{t}}\right)$ vs $\left.\mathrm{t}\right)$ (Eq. 5) or pseudo-second-order kinetic models (plot $1 / q_{\mathrm{t}}$ vs $t$ ) (Eq. 6) using $R$-squared value (Tesfaye 2016).

\section{Statistical analysis and modeling of $\mathrm{Cr}(\mathrm{VI})$ adsorption}

Design Expert (version 7.0.0) software was used for statistical data analysis. The analysis was carried out using the response surface methodology (RSM) through three level central composite design (CCD) (Emirie 2015). The statistical analysis that was performed includes model selection, model fitness test, and ANOVA analysis. A model was selected depending on $p$ value, lack of fit, and R-squared values. The effect of each independent variables and their interactions on the response variable were evaluated by ANOVA. Log transformed second-order polynomial regression was also used to evaluate the magnitude and direction of the effect of individual process parameters [pH (A), initial concentration of $\mathrm{Cr}(\mathrm{VI})(\mathrm{B})$, adsorbent dose (C), and contact time (D)] and their interaction on the removal efficiency of THAC. R-squared value was also used to select the better fit isothermal and kinetics model of the adsorption.

\section{Data quality control}

The chemicals used in the study were standardized. The flame atomic absorption spectrometer (FAAS) was calibrated with seven standard solutions of $\mathrm{Cr}(\mathrm{VI})(0,2,4,6,8$, 10 , and $12 \mathrm{ppm})$. Then, the calibration curves were drawn (absorbance vs concentration of $\mathrm{Cr}(\mathrm{VI})$ ), and the analysis of samples was performed when the R-squared is greater than 0.99 (Annex 1 in supplementary material).

\section{Results and discussion}

\section{Characterization of the Teff husk activated carbon}

The physicochemical characteristics of THAC (Table 3) show as the prepared activated carbon has good quality to be used as an adsorbent for removal of hexavalent chromium from aqueous solution. As clearly stated on Table 3, the prepared AC contains lower ash content, volatile matter, and moisture content as compared to some of the activated carbons produced from different

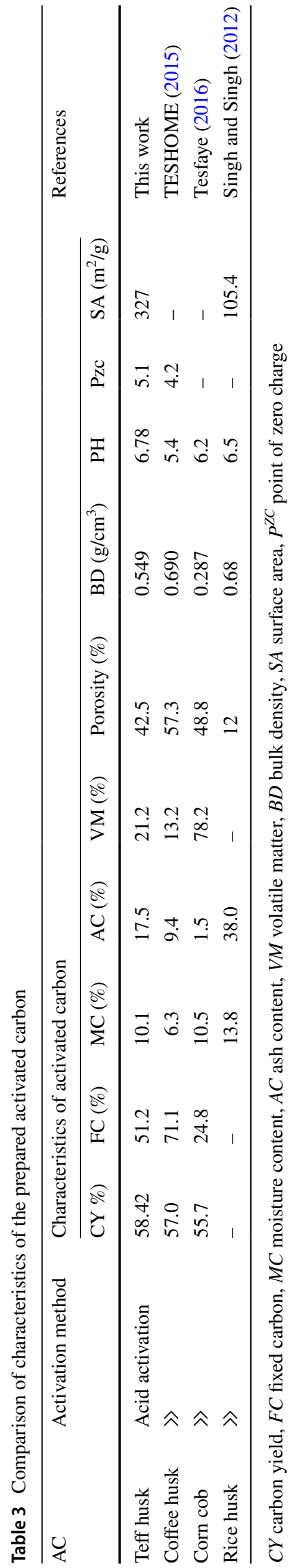


Table 4 Selected levels of process parameters used in optimization through three level central composite design

\begin{tabular}{lccc}
\hline Process parameters & \multicolumn{3}{c}{ Selected levels for optimization } \\
\cline { 2 - 4 } & Low $(-1)$ & Medium $(0)$ & High $(+1)$ \\
\hline $\mathrm{pH}[A]$ & 1.00 & 2.00 & 3.00 \\
Initial concentration of & 50.00 & 100.00 & 150.00 \\
$\quad \mathrm{Cr}(\mathrm{VI})[B]$ (in mg/L) & & & \\
Adsorbent dose $[C]$ (in g/L) & 15.00 & 20.00 & 25.00 \\
Contact time $[D]$ (in h) & 1.50 & 2.00 & 2.50 \\
\hline
\end{tabular}

agro-wastes. Lower ash, volatile matter, and moisture content of THAC indicate as it is highly porous (Kebede and Gashaw 2016), contain lower non-carbonaceous content, and hydrophobic in its nature, respectively (Tesfaye 2016). The high carbon yield and fixed carbon of THAC were also supportive for the feasibility of production of THAC adsorbent (Mussatto et al. 2010). The carbon yield of THAC is also significantly higher than those observed for other lignocellulose materials such as coffee husk and corncob-based activated carbons (Tesfaye 2016; TESHOME 2015). According to American Water Work Association, to the feasibility practical use of an activated carbon, it's the bulk density should not to be less than $0.25 \mathrm{~g} / \mathrm{cm}^{3}$ (Devi et al. 2012). The bulk density and porosity of the prepared THAC were found to be $0.549 \mathrm{~g} / \mathrm{cm}^{3}$ and $42.5 \%$ as stated in Table 3 , which is enough porous with higher surface area and satisfies the above condition. The $\mathrm{p}^{\mathrm{H}}$ and $\mathrm{p}^{\mathrm{zc}}$ of the prepared activated carbon become 6.78 and 5.1, respectively (Table 3 ). The cause for acidic $\mathrm{p}^{\mathrm{zc}}$ of prepared Teff husk activated carbon may be due to the presence of acidic functional groups such as carboxyl, phenolic, and others on the surface of THAC (TESHOME 2015).

The surface functional groups of THAC that show the change after loading of $\mathrm{Cr}(\mathrm{VI})$ were determined. As shown in Fig. 1, the strong peaks of IR spectra were observed at $3466 \mathrm{~cm}^{-1}, 1631 \mathrm{~cm}^{-1}$, and $1106 \mathrm{~cm}^{-1}$ and represents the presence of hydroxyl $(-\mathrm{OH})$, unsaturated $\mathrm{C}=\mathrm{C},-\mathrm{C}-\mathrm{O}-$ groups on the surface of THAC, respectively; which plays a great role in the adsorption process. In the present study, FT-IR spectrum shows that the transmittance band observed at $1106 \mathrm{~cm}^{-1}$ decreases to $1095 \mathrm{~cm}^{-1}$ after adsorption. This shift can be enlightened by the formation weak and broken bands of $-\mathrm{C}-\mathrm{O}$, which resulted from $\mathrm{Cr}(\mathrm{VI})$ bonding with carbonyl groups, could not be observed in the spectrum. Therefore, it can be considered as $\mathrm{Cr}(\mathrm{VI})$ ion may be chemically adsorbed on the surface of the THAC (Sencan and Kiliç 2015). These functional groups were also found in other agrowaste-based activated carbons (TESHOME 2015; Tadesse et al. 2015).

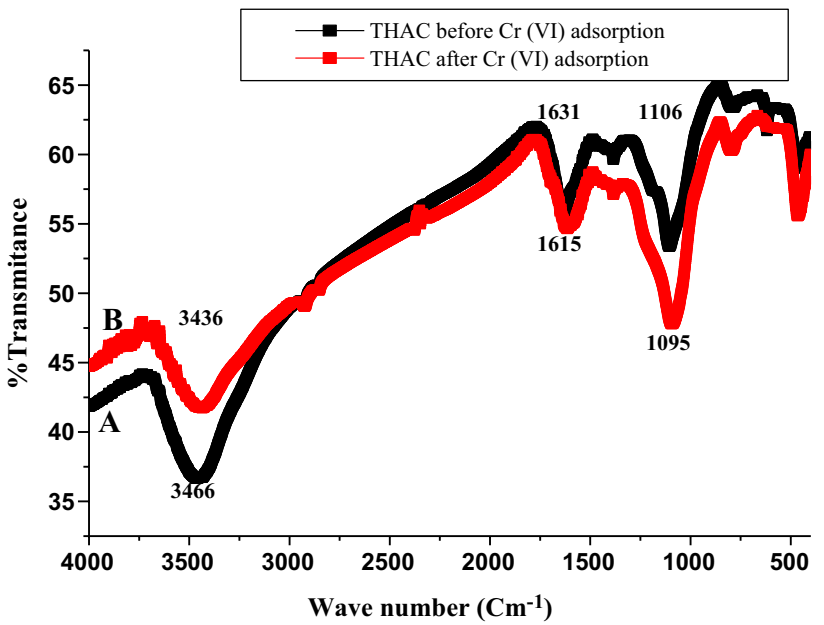

Fig. 1 FT-IR spectra of THAC in $\mathrm{KBr}$ disk; a before $\mathrm{Cr}(\mathrm{VI})$ adsorption and $\mathbf{b}$ after $\mathrm{Cr}(\mathrm{VI})$ adsorption

\section{Effect of experimental parameters on adsorption of $\mathrm{Cr}(\mathrm{VI})$ on the THAC}

\section{Effect of solution $\mathrm{pH}$ on adsorption}

The current study depicted that uptake of $\mathrm{Cr}(\mathrm{VI})$ decreases with increasing $\mathrm{pH}$ as shown in Fig. 2a. This might be due to at lower $\mathrm{pH}$, number of $\mathrm{OH}^{-}$groups becomes decrease, and the net positive charge of activated carbon becomes increase. This leads to high electrostatic force for the adsorption of chromate anions (acid chromate $\left(\mathrm{HCrO}_{4}{ }^{-}\right)$, chromate $\left(\mathrm{CrO}_{4}{ }^{2-}\right)$, and dichromate $\left(\mathrm{Cr}_{2} \mathrm{O}_{7}{ }^{2-}\right)$ ions $)$ on the positive surface of activated carbon (Mullick et al. 2017; Kakavandi et al. 2014; Dula et al. 2014). Maximum Cr(VI) removal efficiency was obtained at $\mathrm{pH} 2$, which is in line with the actual $\mathrm{pH}$ of most industrial effluents such as tannery, electroplating, and chromium plating effluent. This depicts that THAC can be used as the best choice for removal of $\mathrm{Cr}(\mathrm{VI})$ from most industrial effluents (Alemayehu et al. 2011). While application of THAC for treatment of effluents with higher $\mathrm{pH}$, adjustment of the $\mathrm{pH}$ would be required prior to adsorption (Itankar and Patil 2014). The finding was in close agreement with other studies (Dula et al. 2014; Renuga et al. 2010; Singh and Singh 2012; Zhang et al. 2012; Tadesse et al. 2015).

\section{Effect of initial concentration of $\mathrm{Cr}(\mathrm{VI})$ on adsorption}

The result shown in Fig. 2b shows that as the initial concentration of $\mathrm{Cr}(\mathrm{VI})$ increases, its removal efficiency becomes decrease. At higher concentration, the available sites of adsorption to initial number of metals become fewer and the removal efficiency becomes decreased (Tadesse et al. 2015). The maximum removal efficiency was also achieved

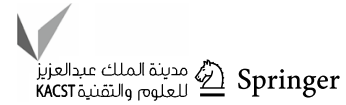


Fig. 2 Effect of $\mathbf{a} \mathrm{pH}, \mathbf{b}$ initial conc. of $\mathrm{Cr}(\mathrm{VI})$, c dose of THAC, $\mathbf{d}$ contact time on the $\mathrm{Cr}(\mathrm{VI})$ removal efficiency of THAC: adsorption condition: volume of solution $100 \mathrm{~mL}$, $\mathrm{pH} 2, \mathrm{Cr}(\mathrm{VI})$ conc. $100 \mathrm{mg} / \mathrm{L}$, amount of THAC $2.0 \mathrm{~g}$, contact time $2 \mathrm{~h}$, and temperature $25^{\circ} \mathrm{C}$
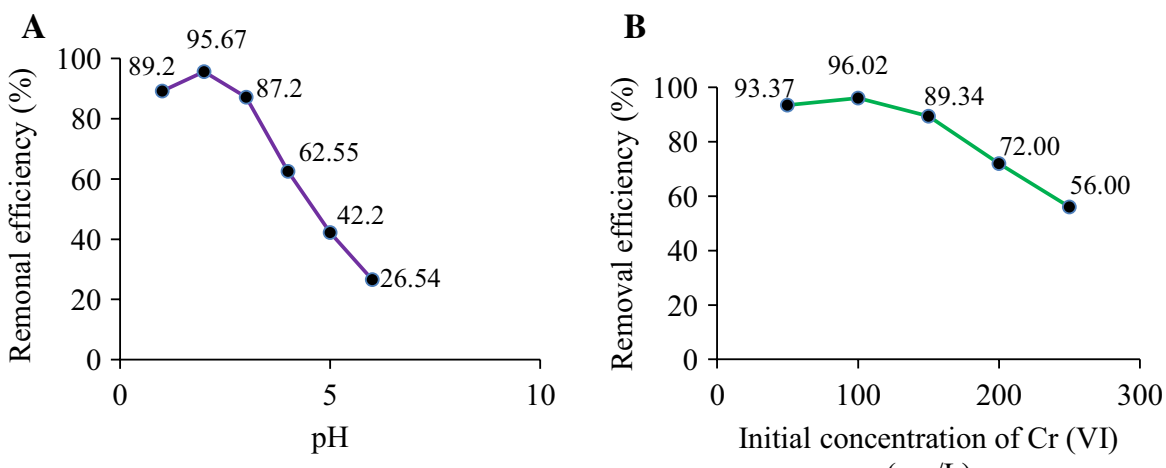

$(\mathrm{mg} / \mathrm{L})$

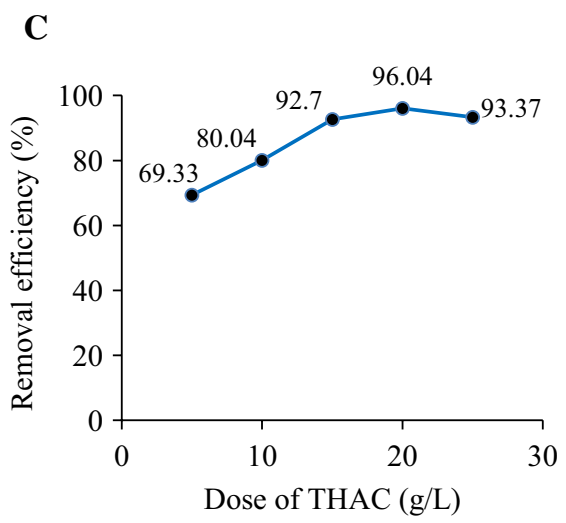

at $100 \mathrm{mg} / \mathrm{L}$ initial concentration of the metal. This result is also in agreement with other studies conducted on different agro-waste-based ACs (Dula et al. 2014; Berihun 2017).

\section{Effect of adsorbent dose on adsorption}

As clearly shown in Fig. 2c, the removal efficiency of THAC becomes increase with increase in the dose of activated carbon. This may be due to the availability of more adsorption sites for the metal ions (Emirie 2015; Gnanasundaram et al. 2017). But further increase in dose of activated carbon leads to decrease in the removal efficiency. This may also due to instauration of the active sites on the adsorbent surface and aggregation resulting from high adsorbate concentrations (Kakavandi et al. 2014; Tesfaye 2016). The maximum removal efficiency was also achieved with an adsorbent dose of $20 \mathrm{~g} / \mathrm{L}$ or $2 \mathrm{~g} / 100 \mathrm{ml}$ of solution. This finding is also consistent with other studies (Kebede and Gashaw 2016; Azimi et al. 2017; Devi et al. 2012).

\section{Effect of contact time on adsorption}

In this study, the removal efficiency of THAC increases with increasing the contact time. But it starts to fall down for an increase in time beyond the equilibrium time. This is because the extent of adsorption increased rapidly in the initial stages due to the presence of large number of unoccupied active sites of an activated carbon. But after a certain time, most sites may be occupied and the remaining sites may be difficult to occupy because of repulsive forces between adsorbate ions on the solid and in the solution (Devi et al. 2012). The maximum removal efficiency was achieved at the equilibrium point after $2 \mathrm{~h}$ contact time. This finding is also in agreement with other studies conducted on agro-waste activated carbons.

\section{Optimum condition for $\mathrm{Cr}(\mathrm{VI})$ removal using THAC}

\section{Chromium (VI) adsorption modeling and model analysis}

The three levels of each four process parameters were selected based on the highest removal efficiency from batch adsorption experiment. The response surface methodology and CCD were used to select the model and to optimize adsorption conditions.

The interaction effect of four studied variables $\mathrm{pH}(\mathrm{A})$, initial concentration of $\mathrm{Cr}(\mathrm{VI})(\mathrm{B})$, adsorbent dose (C), and contact time (D) on the removal efficiency of $\mathrm{Cr}(\mathrm{VI})$ was studied with 30 random experimental runs generated by CCD. The adsorption of $\mathrm{Cr}(\mathrm{VI})$ on THAC in terms of removal efficiency was found to be in range from 76.27 to $95.77 \%$ (Table 5). The actual removal efficiency was also found in close agreement with the predicted removal efficiency of THAC. 
Table 5 Experimental design matrix generated by CCD for removal of $\mathrm{Cr}(\mathrm{VI})$ on Teff husk activated carbon

\begin{tabular}{|c|c|c|c|c|c|c|c|c|}
\hline \multirow[t]{2}{*}{ Standard order } & \multirow[t]{2}{*}{ Run order } & \multicolumn{4}{|c|}{ Actual variables } & \multicolumn{2}{|c|}{ Removal efficiency (\%) } & \multirow[t]{2}{*}{ Relative error } \\
\hline & & A & B & $\mathrm{C}$ & $\mathrm{D}$ & Experimental & Predicted & \\
\hline 11 & 1 & 1.00 & 150.00 & 15.00 & 2.50 & 76.27 & 76.18 & 0.09 \\
\hline 30 & 2 & 2.00 & 100.00 & 20.00 & 2.00 & 95.77 & 95.22 & 0.55 \\
\hline 15 & 3 & 1.00 & 150.00 & 25.00 & 2.50 & 78.12 & 78.15 & -0.03 \\
\hline 24 & 4 & 2.00 & 100.00 & 20.00 & 2.50 & 91.84 & 91.71 & 0.13 \\
\hline 27 & 5 & 2.00 & 100.00 & 20.00 & 2.00 & 95.17 & 95.22 & -0.05 \\
\hline 22 & 6 & 2.00 & 100.00 & 25.00 & 2.00 & 93.17 & 93.10 & 0.07 \\
\hline 4 & 7 & 3.00 & 150.00 & 15.00 & 1.50 & 73.23 & 73.16 & 0.07 \\
\hline 18 & 8 & 3.00 & 100.00 & 20.00 & 2.00 & 87.17 & 87.05 & 0.12 \\
\hline 5 & 9 & 1.00 & 50.00 & 25.00 & 1.50 & 78.05 & 78.00 & 0.05 \\
\hline 23 & 10 & 2.00 & 100.00 & 20.00 & 1.50 & 89.84 & 89.87 & -0.03 \\
\hline 10 & 11 & 3.00 & 50.00 & 15.00 & 2.50 & 81.01 & 81.04 & -0.03 \\
\hline 8 & 12 & 3.00 & 150.00 & 25.00 & 1.50 & 77.67 & 77.68 & -0.01 \\
\hline 16 & 13 & 3.00 & 150.00 & 25.00 & 2.50 & 76.34 & 76.33 & 0.01 \\
\hline 12 & 14 & 3.00 & 150.00 & 15.00 & 2.50 & 73.23 & 73.30 & -0.07 \\
\hline 26 & 15 & 2.00 & 100.00 & 20.00 & 2.00 & 95.17 & 95.22 & -0.05 \\
\hline 6 & 16 & 3.00 & 50.00 & 25.00 & 1.50 & 77.11 & 77.19 & -0.08 \\
\hline 13 & 17 & 1.00 & 50.00 & 25.00 & 2.50 & 81.01 & 81.07 & -0.06 \\
\hline 29 & 18 & 2.00 & 100.00 & 20.00 & 2.00 & 95.17 & 95.22 & -0.05 \\
\hline 17 & 19 & 1.00 & 100.00 & 20.00 & 2.00 & 89.17 & 89.20 & -0.03 \\
\hline 25 & 20 & 2.00 & 100.00 & 20.00 & 2.00 & 94.81 & 95.22 & -0.41 \\
\hline 21 & 21 & 2.00 & 100.00 & 15.00 & 2.00 & 91.84 & 91.81 & 0.03 \\
\hline 19 & 22 & 2.00 & 50.00 & 20.00 & 2.00 & 93.01 & 92.85 & 0.16 \\
\hline 28 & 23 & 2.00 & 100.00 & 20.00 & 2.00 & 94.91 & 95.22 & -0.31 \\
\hline 3 & 24 & 1.00 & 150.00 & 15.00 & 1.50 & 75.45 & 75.49 & -0.04 \\
\hline 7 & 25 & 1.00 & 150.00 & 25.00 & 1.50 & 79.00 & 78.96 & 0.04 \\
\hline 14 & 26 & 3.00 & 50.00 & 25.00 & 2.50 & 79.68 & 79.67 & 0.01 \\
\hline 2 & 27 & 3.00 & 50.00 & 15.00 & 1.50 & 77.01 & 77.02 & -0.01 \\
\hline 1 & 28 & 1.00 & 50.00 & 15.00 & 1.50 & 78.99 & 78.99 & 0 \\
\hline 20 & 29 & 2.00 & 150.00 & 20.00 & 2.00 & 88.78 & 88.85 & -0.07 \\
\hline 9 & 30 & 1.00 & 50.00 & 15.00 & 2.50 & 83.68 & 83.71 & -0.03 \\
\hline
\end{tabular}

$A \mathrm{pH} ; B$ initial concentration of $\mathrm{Cr}(\mathrm{VI})(\mathrm{mg} / \mathrm{L}), C$ dose of activated carbon $(\mathrm{g} / \mathrm{L}), D$ contact time $(\mathrm{h})$
The quadratic model was found to be the highest order polynomial function with maximum adjusted R-squared value (0.9994) (Table 6) and was selected as the best model to represent chromium (VI) efficiency of THAC. This is also consistent with the studies conducted on the removal of $\mathrm{Cr}(\mathrm{VI})$ using different agro-waste-based activated carbons (Emirie 2015; Gnanasundaram et al. 2017; Aravind et al. 2016).

\section{ANOVA and Log transformed second-order quadratic regression}

Different diagnostic and influence plots were also examined to test the effect of outliers and satisfaction of the assumptions of the analysis of variance. All plots revealed that the model has satisfied the assumption of ANOVA (Annex 2 in supplementary material). As given in Table 7, the ANOVA test was performed to examine the
Table 6 Model summary statistics for removal of $\mathrm{Cr}(\mathrm{VI})$ on Teff husk activated carbon

\begin{tabular}{|c|c|c|c|c|c|c|}
\hline Source & SD & $R^{2}$ & Adjusted $R^{2}$ & Predicted $R^{2}$ & PRESS & $\mathrm{RE}$ \\
\hline Linear & 0.0981 & 0.0555 & -0.0957 & -0.3524 & 0.3447 & \\
\hline $2 \mathrm{FI}$ & 0.1111 & 0.0806 & -0.4033 & -2.5672 & 0.9092 & \\
\hline Quadratic & 0.0023 & 0.9997 & 0.9994 & 0.9994 & 0.0002 & Selected \\
\hline Cubic & 0.0031 & 0.9997 & 0.9989 & 0.9976 & 0.0006 & Aliased \\
\hline
\end{tabular}


Table 7 ANOVA table for removal efficiency (natural log transformed removal efficiency)

\begin{tabular}{lllllr}
\hline Source & DF & Sum of squares & Mean square & $F$ value & Prob $>F$ \\
\hline Model & 14 & 0.254802 & 0.0182 & 3490.03 & $<0.0001$ \\
A & 1 & 0.00268 & 0.00268 & 513.87 & $<0.0001$ \\
B & 1 & 0.008733 & 0.008733 & 1674.58 & $<0.0001$ \\
C & 1 & 0.000872 & 0.000872 & 167.19 & $<0.0001$ \\
D & 1 & 0.001852 & 0.001852 & 355.16 & $<0.0001$ \\
AB & 1 & $3.69 \mathrm{E}-05$ & $3.69 \mathrm{E}-05$ & 7.0850 & 0.0178 \\
AC & 1 & 0.000222 & 0.000222 & 42.58 & $<0.0001$ \\
AD & 1 & $5.06 \mathrm{E}-05$ & $5.06 \mathrm{E}-05$ & 9.69 & 0.0071 \\
BC & 1 & 0.003311 & 0.003311 & 634.96 & $<0.0001$ \\
BD & 1 & 0.002407 & 0.002407 & 461.53 & $<0.0001$ \\
CD & 1 & 0.000378 & 0.000378 & 72.41 & $<0.0001$ \\
A^2 & 1 & 0.015535 & 0.015535 & 2978.96 & $<0.0001$ \\
$B^{\wedge} 2$ & 1 & 0.005774 & 0.005774 & 1107.28 & $<0.0001$ \\
$C^{\wedge} 2$ & 1 & 0.002242 & 0.002242 & 429.99 & $<0.0001$ \\
$D^{\wedge} 2$ & 1 & 0.005879 & 0.005879 & 1127.31 & $<0.0001$ \\
Residual & 15 & $7.82 \mathrm{E}-05$ & $5.21 \mathrm{E}-06$ & & \\
Lack of Fit & 10 & $1.64 \mathrm{E}-05$ & $1.64 \mathrm{E}-06$ & 0.133 & 0.9964 \\
Pure Error & 5 & $6.18 \mathrm{E}-05$ & $1.24 \mathrm{E}-05$ & & \\
Cor Total & 29 & & 0.25488 & & \\
\hline
\end{tabular}

$A \mathrm{pH} ; B$ initial concentration of $\mathrm{Cr}(\mathrm{VI}), C$ dose of activated carbon, $D$ contact time

significance of the individual factors and their interaction on the removal efficiency of THAC. $p$ values less than 0.05 indicate model terms were significant. In this study, $A, B$, $C, D, A B, A C, A D, B C, B D, C D, A^{2}, B^{2}, C^{2}, D^{2}$ were significant model terms. This indicated that all the parameters are significant process parameters to the removal efficiency of THAC. This finding is also in agreement with other studies conducted on agro-waste-based activated carbons (Tesfaye 2016; Gnanasundaram et al. 2017, Aravind et al. 2016). Log transformed second-order quadratic regression was also done to estimate the removal efficiency as a second-order polynomial function of four independent process parameters. By default, the high levels of the factors were coded as +1 and the low levels are coded as -1 . The coded equation is useful for identifying the relative impact of the factors by comparing the factor coefficients (Aravind et al. 2016).

\section{Estimation of combined effects of the factors}

The CCD method is used to examine the significant effects of the process parameters $(\mathrm{pH}$, initial concentration, adsorbent dose, and contact time) on the removal efficiency of $\mathrm{Cr}(\mathrm{VI})$. By making other variables constant, the effect of interaction of two variables at a time on the responses was investigated and presented below using contour plots and $3 \mathrm{D}$ response surface.

Figure 3a illustrates the 3D plot of combined effect of $\mathrm{pH}$ and initial concentration of $\mathrm{Cr}(\mathrm{VI})$ at constant adsorbent dosage $(20 \mathrm{~g} / \mathrm{L})$ and contact time $(2 \mathrm{~h})$. The removal efficiency gets increase with decrease in $\mathrm{pH}$ until $\mathrm{pH} 2$, and it starts to decline for further lower $\mathrm{pH}$. The removal efficiency also becomes increase with increase adsorbent dose until it reaches $20 \mathrm{~g} / \mathrm{L}$ and decrease with further addition of adsorbent dose. As stated from coded equation of the response variable, the combined effect of $\mathrm{pH}$ and initial concentration of $\mathrm{Cr}(\mathrm{VI})(A$, $\boldsymbol{B})$ affect the removal efficiency negatively with the coefficient of -0.0015 (Eq. 2). It also has a significant effect on removal efficiency with $p$ value of 0.0178 (Table 7). The maximum removal efficiency at all the studied concentrations takes place at $\mathrm{pH} 2$ and at initial concentration of $100 \mathrm{mg} / \mathrm{L}$.

The interaction between $\mathrm{pH}$ and adsorbent dose on $\mathrm{Cr}(\mathrm{VI})$ removal efficiency of THAC is presented in Fig. 3b. The removal efficiency gets increase with decrease in $\mathrm{pH}$ until $\mathrm{pH} 2$, and it starts to decline for further lower $\mathrm{pH}$. It also becomes increase with increasing adsorbent dose until it reaches $20 \mathrm{~g} / \mathrm{L}$ and decrease with further addition of adsorbent dose. As stated from coded equation of the response variable, the combined effect of $\mathrm{pH}$ and adsorbent dose $(A$, $C)$ affects the removal efficiency positively with the coefficient of +0.0037 (Eq. 2). It also has a significant effect on removal efficiency of THAC with $p$ value of less than 0.001 (Table 7). The maximum adsorption of $\mathrm{Cr}(\mathrm{VI})$ ion is obtained at $\mathrm{pH} 2$ and $A C$ dose of $20 \mathrm{~g} / \mathrm{L}$.

Figure $3 \mathrm{c}$ shows that the effect of solution $\mathrm{pH}$ and contact time on the removal efficiency of THAC was significant. The removal efficiency of THAC was increased with increase in contact time until is equilibrium point. It also becomes increase with increasing contact time until it reaches $2 \mathrm{~h}$ and decrease with further increase in contact time. As stated from coded equation of the response variable, the combined effect of $\mathrm{pH}$ and contact time $(A, D)$ affects the removal efficiency negatively with the coefficient of -0.0018 (Eq. 2). It

Ln (removal efficiency) $(\%)=4.56-0.0122 A-0.0220 B+0.0070 C+0.0101 D$

$$
\begin{aligned}
& -0.0015 A B+0.0037 A C-0.0018 A D+0.0144 B C-0.0123 B D-0.0049 C D \\
& -0.0774 A^{2}-0.0472 B^{2}-0.0294 C^{2}-0.0476 D^{2} \text { coded equation }
\end{aligned}
$$




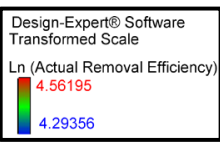

$\mathbf{A}$

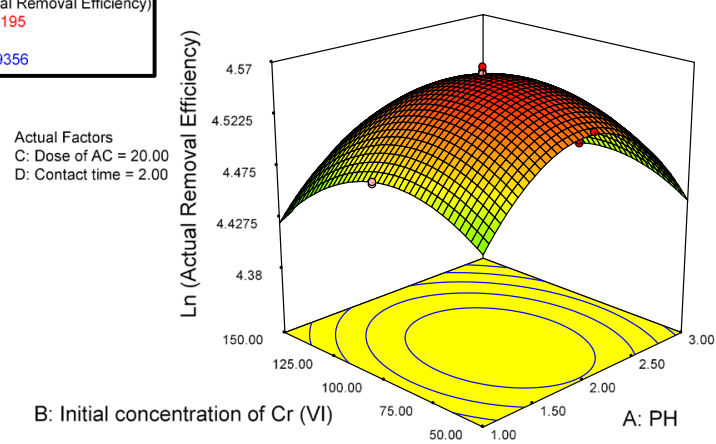

B: Initial concentration of $\mathrm{Cr}(\mathrm{V})$

B

Actual Facto

B: Initial concentration

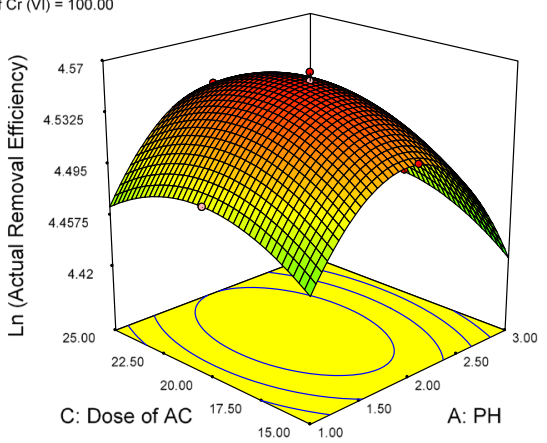

Actual Factors

B: Initial concentration of $\mathrm{Cr}(\mathrm{VI})=100.00$

C: Dose of $A C=20.00$

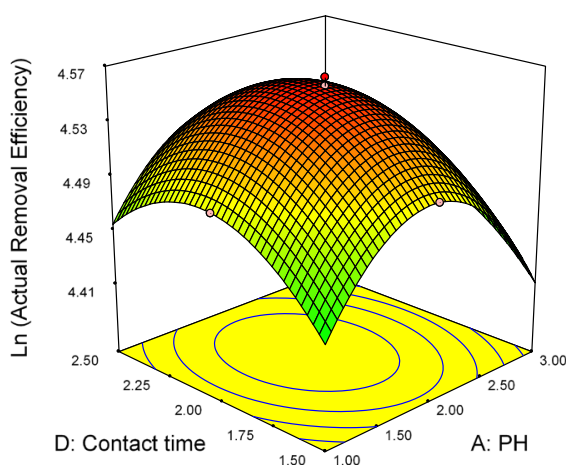

Fig. 3 3D response surface plot of combined effect of a $\mathrm{PH}$ and initial concentration of $\mathrm{Cr}(\mathrm{VI})$. $\mathbf{b} \mathrm{PH}$ and dose of activated carbon: on removal efficiency of THAC. C) PH and contact time. D) Initial concentration of $\mathrm{Cr}(\mathrm{VI})$ and dose of activated carbon on removal effi-

also has a significant effect on removal efficiency of THAC with $p$ value of 0.0071 (Table 7). The maximum removal efficiency was achieved at $\mathrm{pH} 2$ and contact time of $2 \mathrm{~h}$.

The combined effect of initial $\mathrm{Cr}(\mathrm{VI})$ concentration and adsorbent dose on removal efficiency of THAC is shown in Fig. 3d. From the plots, it can be seen that the removal efficiency increases with decrease in the initial $\mathrm{Cr}(\mathrm{VI})$ concentration from 150 to $100 \mathrm{mg} / \mathrm{L}$ and increase in adsorbent dose from 15 to $20 \mathrm{~g} / \mathrm{L}$. As stated from coded equation of the response variable, the combined effect of initial $\mathrm{Cr}(\mathrm{VI})$ concentration and adsorbent dose $(B, C)$ affect the removal

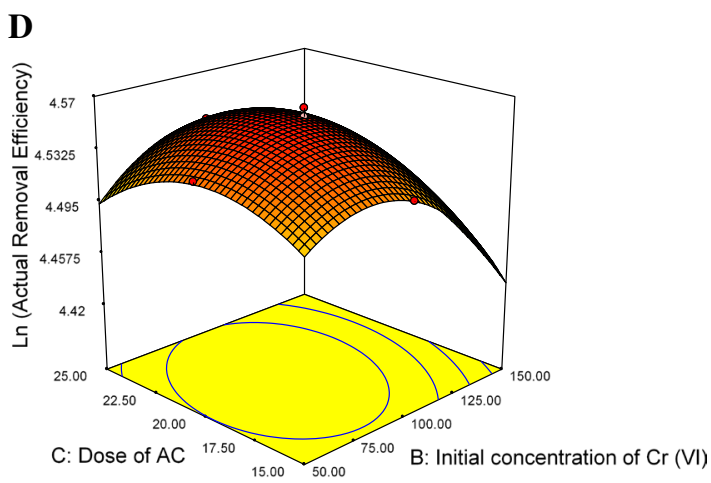

$\mathbf{E}$

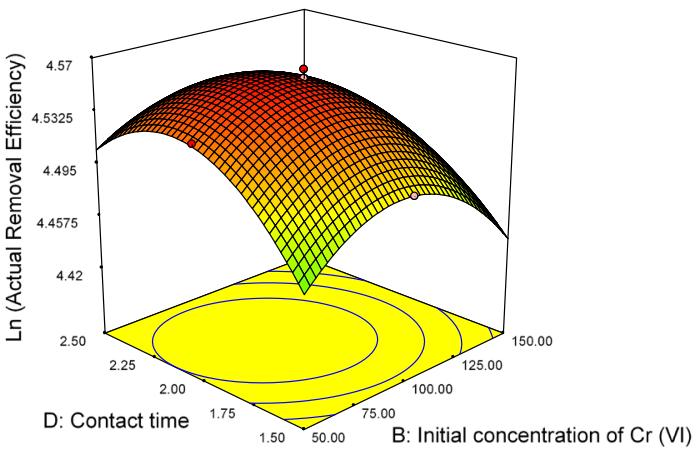

F

A: $\mathrm{PH}=2.00$

A: Pnitial concentration of $\mathrm{Cr}(\mathrm{Vl})=100.00$

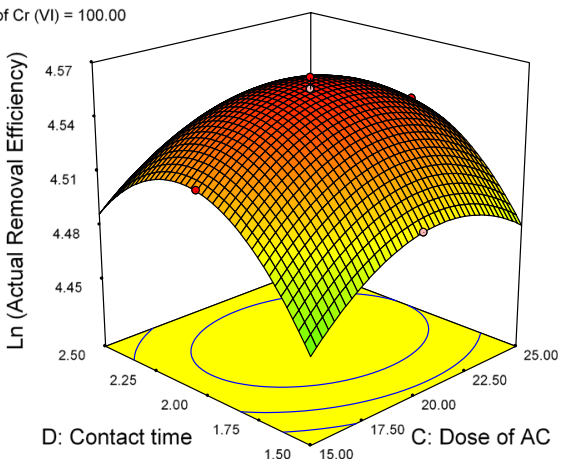

ciency of THAC. E) Initial concentration of $\mathrm{Cr}(\mathrm{VI})$ and contact time. F) Dose of activated carbon and contact time: on removal efficiency of THAC

efficiency positively with the coefficient of +0.0144 (Eq. 2). It also has a significant effect on removal efficiency of THAC with $p$ value of less than 0.001 (Table 7). The maximum removal efficiency was achieved at initial $\mathrm{Cr}(\mathrm{VI})$ concentration from $100 \mathrm{mg} / \mathrm{L}$ and adsorbent dose of $20 \mathrm{~g} / \mathrm{L}$.

The interaction effect of initial $\mathrm{Cr}(\mathrm{VI})$ concentration and contact time on the removal efficiency of THAC is shown in Fig. 3e. The figure revealed that as the contact time increases from 1.5 to $2.0 \mathrm{~h}$, the removal efficiency becomes increased and becomes decreased for longer contact time. As stated from coded equation of the response variable, the 
combined effect of initial $\mathrm{Cr}(\mathrm{VI})$ concentration and contact time (B\&D) affects the removal efficiency negatively with the coefficient of -0.0123 (Eq. 2). This result is also supported by the ANOVA result which showed that the interaction of initial metal $\mathrm{Cr}(\mathrm{VI})$ concentration and contact time has significant effect on the removal efficiency with the $p$ value of less than 0.001 (Table 7). Therefore, the interaction between contact time and initial metal $\mathrm{Cr}(\mathrm{VI})$ concentration has a significant effect on the removal efficiency of THAC.

The combined effect of adsorbent dose and contact time on the removal efficiency of THAC is shown in Fig. 3g. From the plots, it can be seen that the removal efficiency increases with adsorbent dose from 15 to $20 \mathrm{~g} / \mathrm{L}$ and increasing contact time from 1.5 to $2.0 \mathrm{~h}$. As stated from coded equation of the response variable, the combined effect of adsorbent dose and contact time $(C, D)$ affects the removal efficiency negatively with the coefficient of -0.0049 (Eq. 2). It also has a significant effect on removal efficiency of THAC with $p$ value of less than 0.001 (Table 7). It also revealed that the maximum removal efficiency was achieved at an adsorbent dose of $20 \mathrm{~g} / \mathrm{L}$ and $2.0 \mathrm{~h}$ contact time.

\section{Optimized condition for $\mathrm{Cr}(\mathrm{VI})$ removal and validation experiments}

An experiment was conducted to evaluate the optimization result under optimum conditions predicted by the model. The actual experimental removal efficiency of THAC at the optimum condition was in close agreement with model predicted value (Table 8 ). Therefore, the optimization conditions were validated.

\section{Adsorption mechanism}

\section{Adsorption isotherm models}

The Langmuir and Freundlich isotherms were used to describe the mechanism in which the metal ions and active surfaces of an adsorbent are interacted together (Ong et al. 2010).

Langmuir Isotherm according to Langmuir adsorption theory, active sites of adsorbent are homogeneously distributed and the adsorption is monolayer. This is better isotherm to explain chemical adsorption (Abas et al. 2013). The isotherm is represented by:

$\frac{C_{\mathrm{e}}}{q_{\mathrm{e}}}=\frac{1}{b q_{\max }}+\frac{C_{\mathrm{e}}}{q_{\max }}$

The fitness of this isothermal model can be determined from the linear plot of specific adsorption $\left(C_{\mathrm{e}} / q_{\mathrm{e}}\right)$ against the equilibrium concentration $\left(C_{\mathrm{e}}\right)$ as plotted in Fig. $4 \mathrm{a}$. The values of constants, the energy of adsorption $(b)$, and maximum adsorption capacity $\left(q_{\max }\right)$ can be determined from the slope and intercept of the plot (Desta 2013).

Freundlich isotherm model assumes as the active sites of surfaces are heterogeneous; there is an interaction between adsorbed molecules and not restricted to the formation of a monolayer (Abas et al. 2013). The fitness of the model was tested using the linearized equation of Freundlich model:

$\ln q_{\mathrm{e}}=\ln K_{\mathrm{f}}-\frac{1}{n} \ln C_{\mathrm{e}}$

where $q_{\mathrm{e}}$ represents the amount adsorbed per amount of adsorbent at the equilibrium $(\mathrm{mg} / \mathrm{g}), C_{\mathrm{e}}$ represents the equilibrium concentration $(\mathrm{mg} / \mathrm{L})$, and adsorption capacity $\left(K_{\mathrm{f}}\right)$

Table 8 Optimum conditions of the four studied parameters for removal of $\mathrm{Cr}(\mathrm{VI})$ by THAC

\begin{tabular}{|c|c|c|c|c|c|c|c|}
\hline \multirow[t]{2}{*}{ Process parameters } & \multirow[t]{2}{*}{$\mathrm{pH}$} & \multirow[t]{2}{*}{ Initial conc. of $\mathrm{Cr}(\mathrm{VI})$} & \multirow[t]{2}{*}{ Dose of AC } & \multirow[t]{2}{*}{ Contact time } & \multicolumn{2}{|c|}{ Removal efficiency } & \multirow[t]{2}{*}{ Desirability } \\
\hline & & & & & predicted $(\%)$ & actual $(\%)$ & \\
\hline Optimized condition & 1.92 & $87.83 \mathrm{mg} / \mathrm{L}$ & $20.22 \mathrm{~g} / \mathrm{L}$ & $2.07 \mathrm{~h}$ & $95.60 \%$ & $95.57 \%$ & 0.993 \\
\hline
\end{tabular}

Fig. 4 Plot of a Langmuir isotherm model, b Freundlich isotherm model fitness at conditions of: volume of solution $=100 \mathrm{~mL}$, initial $\mathrm{Cr}(\mathrm{VI})$ concentration $=100,150,200$, $250 \mathrm{mg} / \mathrm{L}, \mathrm{pH}=2$, amount of THAC $=2 \mathrm{~g}$, contact time $=2 \mathrm{~h}$ at temperature of $25^{\circ} \mathrm{C}$
A Langmuir Isotherm model

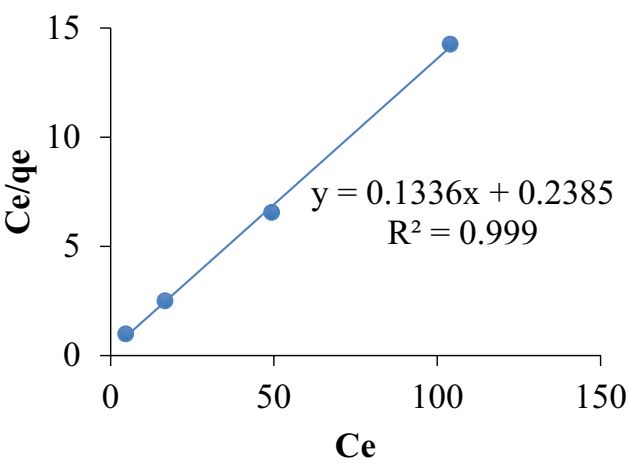

B Freundlich isotherm model

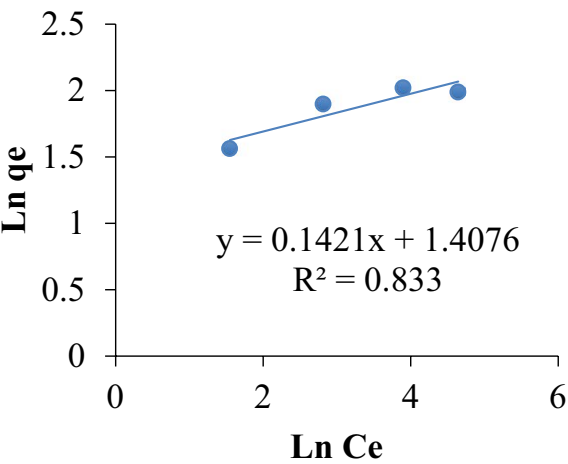


and adsorption intensity ( $n$ ) are Freundlich constants whose value can be determined from the plot of $\ln q_{\mathrm{e}}$ versus $\ln C_{\mathrm{e}}$ as plotted in Fig. 4b.

Results stated on Fig. 4 revealed that the higher correlation coefficient is observed using the Langmuir isothermal model. This implies that the model is best fitted to explain $\mathrm{Cr}$ (VI) adsorption on THAC. So the active sites of THAC were homogeneously distributed and the adsorption was monolayer and chemical adsorption (Emirie 2015).

\section{Adsorption kinetics models}

Adsorption kinetics represents the solute removal rate. Information on adsorption kinetics can also be used to select the optimum condition for full-scale removal processes design (Tesfaye 2016).

Pseudo-first order kinetics model refers to the assumption of the rate of change of solute uptake with time which is directly proportional to the difference in the saturation concentration and the amount of solid uptake with time. The fitness of pseudo-first order kinetic model was tested using the linearized equation of Lagergren model is given by (Emirie 2015):

$\log \left(q_{\mathrm{e}}-q_{\mathrm{t}}\right)=\log q_{\mathrm{e}}-\frac{K_{1}}{2.303} t$

where $q_{\mathrm{e}}$ and $q_{\mathrm{t}}$ are the amount of adsorbed adsorbate $(\mathrm{mg} / \mathrm{g})$ at an equilibrium and at any instant of time $\mathrm{t}(\mathrm{min})$, respectively, and $k_{1}$ is the rate constant of pseudo-first order adsorption operation $\left(\min ^{-1}\right)$. The values of $K_{1}$ and $q_{\mathrm{e}}$ can be determined from the slop and intercept of the plot of log $\left(q_{\mathrm{e}}-q_{\mathrm{t}}\right)$ versus $\mathrm{t}$, respectively, as plotted in Fig. 5a.

Pseudo-second-order Kinetics model is based on the assumption that the rate limiting step may stem from the chemical adsorption involving valence forces through the sharing or exchange of electrons between the adsorbent and adsorbate. The fitness of pseudo-second-order kinetic model was tested with the linearized equation given as (Emirie 2015):
$\frac{t}{q_{\mathrm{t}}}=\frac{1}{K_{2}\left(q_{\mathrm{e}}\right)}+\frac{1}{q_{\mathrm{e}}} t$

where $K_{2}$ is the rate constant of pseudo-second-order adsorption operation. The values of $K_{2}$ and $q_{\mathrm{e}}$ can be determined from the slop and intercept of the plot of $t / q_{\mathrm{t}}$ versus $\mathrm{t}$, respectively, as plotted in Fig. 5b.

Results on Fig. 5a, b show that higher correlation was observed by using the pseudo-second-order equation. This implies the pseudo-second-order model provides the best correlation of the data. So the rate limiting step may be caused by chemisorption involving valency forces through sharing or exchange of electrons between adsorbent and adsorbate. The result of isotherm and kinetics studies was also in agreement with other studies conducted to examine the kinetics of $\mathrm{Cr}(\mathrm{VI})$ on activated carbon (Mullick et al. 2017; TESHOME 2015; Tadesse et al. 2015).

\section{Final fate of $\mathrm{Cr}(\mathrm{VI})$ adsorbed THAC}

Since chromium is non-renewable and finite natural resource, application of THAC is not limited for its removal from the wastewater but also outspreads to recovery and recycling of chromium for chrome tanning and other industrial purposes (Itankar and Patil 2014). Therefore, chromium will be recovered and back returned to industry.

\section{Limitation of the study}

In this study, the adsorption was conducted in batch adsorption manner due to short period of the study, so the adsorption is not conducted in column adsorption process which is better fit to design in industries.
Fig. 5 Plot of a pseudo-first order kinetic and $\mathbf{b}$ pseudosecond-order kinetic models at conditions of: volume of solution $=100 \mathrm{~mL}$, initial $\mathrm{Cr}(\mathrm{VI})$ concentration $=100 \mathrm{mg} / \mathrm{L}$, $\mathrm{pH}=2$, amount of THAC $=2 \mathrm{~g}$, contact time $=0.5,1.0,1.5,2.0$ $\mathrm{h}$ at temperature of $25^{\circ} \mathrm{C}$
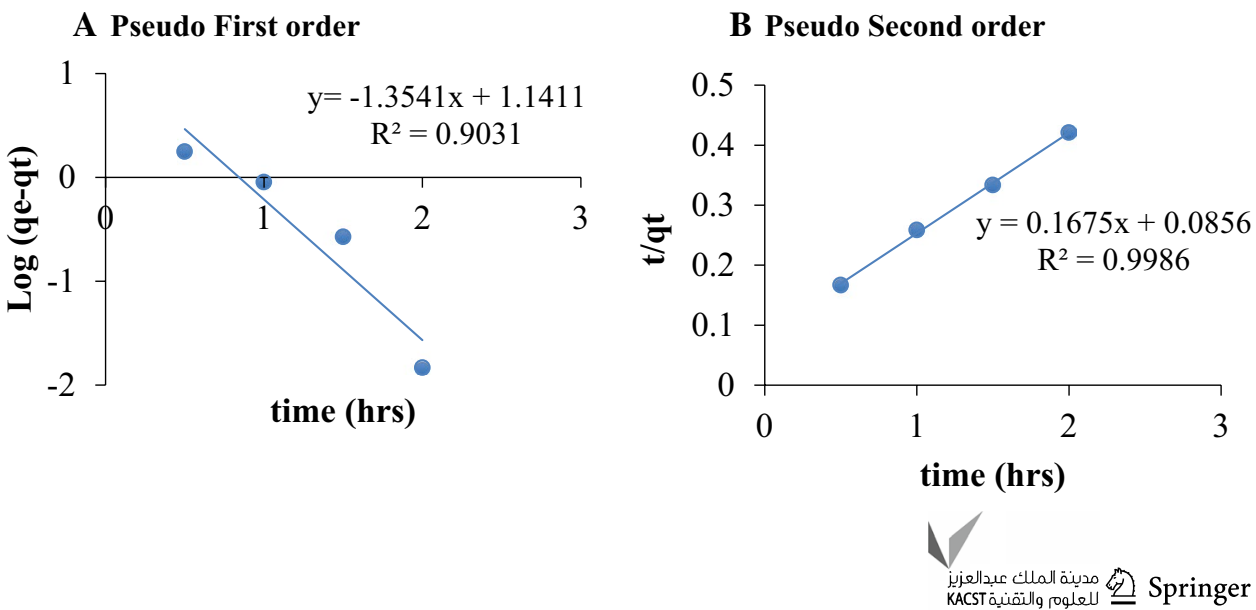


\section{Conclusion and recommendation}

The present study focused on the application of Teff husk activated carbon as an effective and locally available adsorbent for removal of hexavalent chromium from aqueous solution. The optimum $\mathrm{Cr}(\mathrm{VI})$ removal efficiency of THAC (95.597\%) was achieved at $\mathrm{pH} 1.92$, initial concentration of $87.83 \mathrm{mg} / \mathrm{L}$, adsorbent dose of $20.22 \mathrm{~g} / \mathrm{L}$, and contact time of $2.07 \mathrm{~h}$. The adsorption of $\mathrm{Cr}(\mathrm{VI})$ on to THAC was best fitted to pseudo-second-order kinetics model $\left(R^{2}=0.9986\right)$ and Langmuir isotherm model $\left(R^{2}=0.999\right)$. In conclusion, THAC can be used as an effective, locally available, economical, and environmental friendly adsorbent for removal $\mathrm{Cr}(\mathrm{VI})$ removal from contaminated water. Column adsorption needs to be studied in future.

Acknowledgments The authors are pleased to acknowledge University of Gondar for its unreserved contribution to the success of this study.

Funding This research did not receive any specific grant from funding agencies in the public, commercial, or not-for-profit sectors.

\section{Compliance with ethical standards}

Conflict of interest The authors declare that they have no conflict of interest.

Consent for publication All authors read and approved the manuscript.

Open Access This article is licensed under a Creative Commons Attribution 4.0 International License, which permits use, sharing, adaptation, distribution and reproduction in any medium or format, as long as you give appropriate credit to the original author(s) and the source, provide a link to the Creative Commons licence, and indicate if changes were made. The images or other third party material in this article are included in the article's Creative Commons licence, unless indicated otherwise in a credit line to the material. If material is not included in the article's Creative Commons licence and your intended use is not permitted by statutory regulation or exceeds the permitted use, you will need to obtain permission directly from the copyright holder. To view a copy of this licence, visit http://creativecommons.org/licenses/by/4.0/.

\section{References}

Abas SNA, Ismail MHS, Kamal ML, Izhar S (2013) Adsorption process of heavy metals by low-cost adsorbent: a review. World Appl Sci J 28:1518-1530

Alemayehu E, Thiele-Bruhn S, Lennartz B (2011) Adsorption behaviour of $\mathrm{Cr}(\mathrm{VI})$ onto macro and micro-vesicular volcanic rocks from water. Sep Purif Technol 78:55-61

Ali IH, Alrafai HA (2016) Kinetic, isotherm and thermodynamic studies on biosorption of chromium(VI) by using activated carbon from leaves of Ficus nitida. Chem Cent J 10:36

Ali A, Saeed K, Mabood F (2016) Removal of chromium(VI) from aqueous medium using chemically modified banana peels as efficient low-cost adsorbent. Alex Eng J 55:2933-2942
Aravind J, Kanmani P, Sudha G, Balan R (2016) Optimization of chromium(VI) biosorption using gooseberry seeds by response surface methodology. Glob J Environ Sci Manag 2:61-68

ASTM (1999a) ASTM D2867-99, standard test methods for moisture in activated carbon. www.astm.org. ASTM International, West Conshohocken, PA

ASTM (1999b) ASTM D3838-80, standard test method for $\mathrm{pH}$ of activated carbon. www.astm.org. ASTM International, West Conshohocken, PA

ASTM (2003) Annual book of ASTM standards, standard test method for volatile matter content of activated carbon samples, ASTM D5832-95. United State of America, Philadelphia, PA

ASTM (2004a) ASTM D2854-96(2004), standard test method for apparent density of activated carbon. www.astm.org. ASTM International, West Conshohocken, PA

ASTM (2004b) ASTM D2866-94, standard test method for total ash content of activated carbon. www.astm.org. ASTM International, West Conshohocken, PA

Azimi A, Azari A, Rezakazemi M, Ansarpour M (2017) Removal of heavy metals from industrial wastewaters: a review. ChemBioEng Rev 4:37-59

Berihun D (2017) Removal of chromium from industrial wastewater by adsorption using coffee husk. J Mater Sci Eng 6:2

Birhanie M, Leta S, Khan MM (2017) Removal of hazardous pollutants from tannery wastewater by naval filter medium (pumice) through adsorption and filtration method. IOSR J Environ Sci Toxicol Food Technol (IOSR-JESTFT) II:38-45

Black-Smith-Institute (2015) World's worst pollution problems

Desta MB (2013) Batch sorption experiments: langmuir and freundlich isotherm studies for the adsorption of textile metal ions onto Teff straw (Eragrostis tef) agricultural waste. J Thermodyn 2:6

Devi BV, Jahagirdar AA, Ahmed MNZ (2012) Adsorption of chromium on activated carbon prepared from coconut shell. Int J Eng Res Appl (IJERA) 2:364-370

Dula T, Siraj K, Kitte SA (2014) Adsorption of hexavalent chromium from aqueous solution u sing chemically activated carbon prepared from locally available waste of bamboo (Oxytenanthera abyssinica). ISRN Environ Chem 9

Emirie M (2015) Removal of chromium hexavalent (Cr(VI) from aqueous solution using activated carbon prepared from Prosopis Juliflora plant and find the optimal operating condition for adsorption process. Addis Ababa University, Addis Ababa

Gebretsadik H, Haile M, Yamoah CF (2009) Tillage frequency, soil compaction and $\mathrm{N}$-fertilizer rate effects on yield of Teff (Eragrostis tef (Zucc) Trotter) in central zone of Tigray, Northern Ethiopia. Momona Ethiop J Sci 1.

Gnanasundaram N, Loganathan M, Singh A (2017) Optimization and performance parameters for adsorption of $\mathrm{Cr}^{6+}$ by microwave assisted carbon from Sterculia foetida shells. In: IOP conference series: materials science and engineering, vol 206

Itankar N, Patil Y (2014) Management of hexavalent chromium from industrial waste using low-cost waste biomass. Procedia Soc Behav Sci 133:219-224

Kakavandi B, Kalantary RR, Farzadkia M, Mahvi AH, Esrafili A, Azari A, Yari AR, Javid AB (2014) Enhanced chromium (VI) removal using activated carbon modified by zero valent iron and silver bimetallic nanoparticles. Journal of environmental health science and engineering. 12:115

Kebede F, Gashaw A (2016) Removal of chromium and azo metalcomplex dyes using activated carbon synthesized from tannery wastes. Open Access J Sci Technol 5:30

Kibatu G, Chacha R, Kiende R (2017) Determination of major, minor and trace elements in Tef using portable total $\mathrm{X}$-ray fluorescence (TXRF) spectrometer. EC Nutr 9:51-59 
Magoling BJA, Macalalad AA (2017) Optimization and response surface modelling of activated carbon production from Mahogany fruit husk for removal of chromium (VI) from aqueous solution. BioResources 12:3001-3016

MiningWatch (2012) Potential toxic effects of chromium, chromite mining and ferrochrome production: a literature review. MiningWatch Canada

Mullick A, Moulik S, Bhattacharjee S (2018) Removal of hexavalent chromium from aqueous solutions by low-cost rice husk-based activated carbon: kinetic and thermodynamic studies. Indian Chem Eng. 60(1):58-71

Mussatto SI, Fernandes M, Rocha GJM, Órfão JJM, Teixeira JA, Roberto IC (2010) Production, characterization and application of activated carbon from brewer's spent grain lignin. Biores Technol 101:2450-2457

Ong S-A, Toorisakaa E, Hirataa M, Hanoa T (2010) Adsorption and toxicity of heavy metals on activated sludge. ScienceAsia 36:204-209

Rai MK, Shahi G, Meena V, Meena R, Chakraborty S, Singh RS, Rai BN (2016) Removal of hexavalent chromium Cr(VI) using activated carbon prepared from mango kernel activated with $\mathrm{H} 3 \mathrm{PO} 4$. Resour-Eff Technol 2:S63-S70

Renuga DEVI, Manjusha K, Manjusha P (2010) Removal of Hexavalent Chromium from aqueous solution using an eco-friendly activated carbon adsorbent. Adv Appl Sci Res 1:247-254

Sato T, Qadir M, Yamamoto S, Endo T, Zahoor A (2013) Global, regional, and country level need for data on wastewater generation, treatment, and use. Agric Water Manag 130:1-13

Şencan A, Kılıç M (2015) Investigation of the changes in surface area and FT-IR spectra of activated carbons obtained from hazelnut shells by physicochemical treatment methods. J Chem

Singh SR, Singh AP (2012) Treatment of water containg chromium (VI) using rice husk carbon as a newlow cost adsorbent. Int J Environ Res 6:917-924
Solomon F (2008) Impacts of metals on aquatic ecosystems and human health. Environ Commun

Stallknecht GF, Gilbertson KM, Eckhoff J (1993) Teff: food crop for humans and animals. New crops, Wiley, New York, pp 231-234

Tadesse B, Teju E, Megersa N (2015) The Teff straw: a novel low-cost adsorbent for quantitative removal of $\mathrm{Cr}(\mathrm{VI})$ from contaminated aqueous samples. Desalination Water Treat 56:2925-2936

Tesfaye D (2016) Removal of lead from waste water using corn cob activated carbon as an adsorbent. AAU, ResearchGate

Teshome A (2015) Preparation, characterization and application of coffee husk based activated carbon for adsorption of $\mathrm{Cr}(\mathrm{VI})$ from aqueous solution. Adiss Abeba University, Adiss Abeba

UN-WWAP (2017) The United Nations world water development report. wastewater: the untapped resource. UNESCO, Paris

Vandercasteelen J, Dereje M, Minten B, Taffesse AS (2013) Scaling-up adoption of improved technologies: the impact of the promotion of row planting on farmers' Teff yields in Ethiopia. LICOS-discussion paper series 344/2013, pp 1-25

Yimer J, Yadav OP, Kebede T, Mohammed J (2014) Kinetics and equilibrium study of adsorption of phenol red on teff (Eragrostis teff) husk activated carbon. Int J Innov Sci Res 11:471-476

Zhang J, Shang T, Jin X, Gaod J, Zhaoe Q (2012) Study of chromium(VI) removal from Aqueous Solution using nitrogenenriched activated carbon based bamboo processing residues. RSCPublishing, pp 1-3

Publisher's Note Springer Nature remains neutral with regard to jurisdictional claims in published maps and institutional affiliations. 